\title{
Efficiency Analysis of Zakat Intitutions in Indonesia by using Data Envelopment Analysis (DEA)
}

\author{
Nadita Tri Hastutik ${ }^{1}$, M. Soleh Nurzaman ${ }^{2}$ \\ \{naditatrihastutik@gmail.com ${ }^{1}$ \} \\ ${ }^{1,2}$ Islamic Economic, Faculty of Economic and Business, University of Indonesia, Jl. Prof. Dr. Sumitro \\ Djojohadikusumo, Kukusan, Beji, Depok, Jawa Barat,Indonesia
}

\begin{abstract}
Zakat is one of the five pillars of Islam. Zakat has vertical and horizontal relationships where vertical relationship to Allah SWT and horizontal relationship that serves as the distribution of wealth and income. Indonesia is a country with the largest number of Muslims in the world so the potential of ZIS Indonesia is very large. Zakat institution has an important role in zakat management. This study discusses the performance of zakat institutions by conducting an analysis based on the Data Envelopment Analysis (DEA) in BAZIS DKI Jakarta and BAZNAS Bogor, Depok, Tangerang, and Bekasi. This study aims to analyze the performance of BAZNAS and BAZIS in Jabodetabek by using DEA \& to know ranking of efficiency of zakat institutions. Result from this study shows that the average performance by using DEA is 0.642 and 0.752 in 2016 and 2017. In 2016 there were 2 DMUs that were already efficient, namely BAZIS Administration of South and East Jakarta. While, in 2017 there were 4 DMUs that were already efficient, namely BAZIS Administration of South and East Jakarta and BAZNAS Bekasi and Tangerang.
\end{abstract}

Keywords: Zakat, Performance, Zakat Institutions, Data Envelopment Analysis (DEA)

\section{Introduction}

Zakat is a form of obligatory worship to Allah SWT. Zakat is part of the third pillar of Islam. That is, zakat is one of the main pillars of the teachings of Islam. Zakat is not only promoting justice, accountability and compassion in society, but also as a means to preserve social equilibrium in a country by helping the poor and needy to pursue a better life (Khurshid et al., 2014; Abdullah and Sapiei, 2018) From an economic perspective, zakat is one of the instruments of Islam that functions as a distribution of income and wealth. Zakat has been used to mitigate poverty from the days of Prophet Muhammad, as ordained by God (Ahmed and Md Salleh, 2016). In a hadith narrated by Imam al-Ashanani from the Faith at-Thabrani, the Messenger of Allah said that means:

"Verily Allah SWT has obliged the Muslim businessmen to fulfill the obligation of zakat which can overcome poverty. It is not possible for a devotee to suffer from hunger or lack of clothing, except because of the inherent mischief in Muslim journalists. Remember, Allah SWT will do careful calculations and hold them accountable and will further torture them with painful punishment".

Indonesia is the country with the largest number of Muslims in the World. Indonesian Muslim population reaches $85 \%$ or around 216 million of the total population of Indonesia (Central Bureau of Statistics, 2015). This resulted in the potential of zakat in Indonesia is very large and is one solution to overcome the problem of poverty and inequality in Indonesia. Moreover, the problem of poverty and inequality is still a major problem in Indonesia. Table 1 shows that the growth of Zakat, Infaq, and Shadaqah/Alms (ZIS) continued to increase from 
2007 to 2016. The data is the result of reports by various of zakat institutions in Indonesia, including The National Board of Zakat in Indonesia (BAZNAS), BAZNAS Province, BAZNAS Regency/City, Amil Zakat Institution (LAZ), LAZ Province, and LAZ Regency/City which report collection data to BAZNAS officially in accordance with Law $23 / 2011$. The increase occurred in line with improvements in regulation, coordination, and management of the zakat institutions. According to Wibisono (2011), the extent of the zakat institutions network, both LAZ and BAZNAS, became the main force that led to the rising trend of ZIS collection in Indonesia. The extent of the zakat institutions network can facilitate the public in paying ZIS so that it helps the government in collecting ZIS funds nationally.

Table 1. ZIS Collection in Indonesia in 2007-2016 (Billion Rupiahs)

\begin{tabular}{ccc}
\hline Year & ZIS Collection & Growth (\%) \\
\hline 2007 & 740 & - \\
\hline 2008 & 920 & 24.32 \\
\hline 2009 & 1200 & 30.43 \\
\hline 2010 & 1500 & 25.00 \\
\hline 2011 & 1729 & 15.30 \\
\hline 2012 & 2200 & 27.24 \\
\hline 2013 & 2700 & 22.73 \\
\hline 2014 & 3300 & 22.22 \\
\hline 2015 & 3700 & 21.21 \\
\hline 2016 & 5017 & 26.25 \\
\hline
\end{tabular}

Source: National Board of Zakat (BAZNAS)

Although the growth of zakat in Indonesia has increased every year. But there is a gap between the potential of zakat and zakat collection in Indonesia. Zakat potential in Indonesia reaches Rp. 217 Trillion (Indonesia Zakat Outlook, 2018). But in 2017, the collection of national ZIS collected by BAZNAS and LAZ reached Rp. 6 Trillion or only 2.76 percent of the total potential. There are several causes of this gap, one of the causes is the low awareness of compulsory zakat (muzakki) and the low trust in paying zakat to formal institutions (Indonesia Zakat Outlook 2017). Therefore, public trust in zakat institutions has an important role in collecting zakat by zakat institutions. So the standardized performance of zakat institutions is needed so that zakat institutions can be more professional and can increase public awareness and trust to pay zakat formally.

Zakat institutions has a very important role for the performance of zakat in general. Zakat institutions has an obligation to ensure and convince the public that zakat institutions does not only raise funds and distribute in accordance with sharia principles but zakat institutions must be professional and efficient. Zakat institutions can also provide socio-economic impacts and make zakat a productive economic source and provide long-term effects on Mustahik (recipients of zakat). According to Yusuf al-Qaradawi (1973), the role of Amil (zakat officer) is equated to the heart in the human body, if the heart is good, the human body is also good, if the heart hurts, all parts of the body will deteriorate. So that the role of Amil is very strategic and decisive in the rise of zakat. In managing ZIS funds, the role of Amil is very important because Amil carries out the mandate to manage the funds to be distributed to Mustahik. Zakat funds that have been collected must be managed appropriately in order to achieve optimal efficiency and productivity(Noor et al., 2015).

In the Al-Quran, Amil occupies the third position after the poor and poor as parties who receive zakat funds. This indicates that zakat is not an assignment given to someone but also a 
state duty (al-Qaradhawi, 1999)). The state is obliged to regulate and appoint people who work to manage zakat, consisting of collectors, storage, writers, counters and so on. History says that one of the reasons for the fall of the Umayyad Dynasty was the failure of the government to manage Baitulmal (M., 1991). Therefore, the government is obliged to provide facilities and infrastructure in managing zakat both nationally and district/city level.

BAZNAS as a non-structural government agency that is authorized to manage zakat nationally, is independent and responsible to the President through the Minister of Religious Affairs. In addition to the national level, BAZNAS also manages ZIS at the provincial and district/city level. But within the scope of the national capital of Indonesia, DKI Jakarta, the government agency that manages ZIS funds in Jakarta is Badan Amil Zakat, Infaq and Shadaqah (BAZIS). BAZIS DKI Jakarta is equivalent to BAZNAS at the provincial level but structurally BAZIS DKI Jakarta is independent and separated from BAZNAS. In addition to managing ZIS at the provincial level, BAZIS also manages ZIS at the City and District levels. The establishment of a government institution in charge of managing ZIS is proof that the Indonesian government has regulated and provided institutions that manage zakat from the district to the national level.

BAZIS DKI Jakarta is a non-structural government agency owned by the DKI Jakarta's government which also has a substantial acquisition of ZIS. In 2016, Jakarta ZIS collection reached 154.01 billion rupiahs. The latest data shows that BAZIS DKI Jakarta has ZIS collected amounting to 191.25 billion rupiahs in 2017 and targets a ZIS collection of 300 billion rupiahs in 2018 (BAZIS DKI Jakarta, 2018).

Within the scope of the capital city of Indonesia, DKI Jakarta can collect a sizeable of ZIS funds. The sizeable collection in the capital city reflects the progress of zakat management in Indonesia. In addition to the scope of the capital, Bogor, Depok, Tangerang and Bekasi as cities that closest to the capital also continued to increasing the collected of ZIS funds from year on year. BAZNAS Bogor in 2014 managed to raise ZIS funds from 3.4 billion rupiahs while in 2017 managed to raise ZIS funds by 5.6 billion rupiahs, an increase of $64.7 \%$ (BAZNAS Bogor, 2017). BAZNAS Tangerang has a substantial ZIS growth of $222 \%$ from 775 million rupiahs in 2012 to 2.5 billion rupiahs in 2016 (BAZNAS Tangerang, 2016). Meanwhile, BAZNAS Bekasi has a higher collection compared to BAZNAS Kota Depok, Bogor and Tangerang which is equal to 10.1 billion rupiahs in 2017 with a growth of $15 \%$ compared to the previous year. On the other hand, BAZNAS Depok has only been established at the end of 2016 so that ZIS collection tends to be lower compared to BAZNAS Bogor, Bekasi, and Tangerang. But over time, the collection of ZIS in Depok can increase considering the economic development in Depok is increasingly rapid (Ardianto, 2018).

Jakarta, Bogor, Depok, Tangerang, and Bekasi (Jabodetabek) are metropolitan with a population of 30 million (Dardak, 2014). With a large population and tends to increase every year, the potential for ZIS in Jabodetabek is very large. BAZNAS at the district /city level and BAZIS DKI Jakarta only manage zakat in their respective regions so that there is a focus in managing ZIS funds and helping local governments to improve community welfare through the programs they run. Therefore, zakat management must be carried out efficiently and professionally. So the authors feel it is important to conduct research on zakat institutions performance, especially BAZNAS and BAZIS DKI Jakarta at district/city level as nonstructural government institutions.

The object of this research is BAZNAS Depok, Tangerang, Bogor, Bekasi and BAZIS Administration of North, South, East, West and Central Jakarta. The research object covers the Jabodetabek (Jakarta, Bogor, Depok, Tangerang, and Bekasi) area. Jabodetabek is an area that is more advanced than other regions throughout Indonesia so that it can be used as a national 
representation. Performance measurement by using DEA (Data Envelopment Analysis) in BAZNAS Depok, Tangerang, Bogor, Bekasi and BAZIS DKI Jakarta has never been studied so this research can fill the gap from previous research.

This study aims to analyze the performance of BAZNAS in Depok, Tangerang, Bogor, Bekasi and BAZIS Administration of North, South, East, West and Central Jakarta by using DEA and to know ranking of efficiency of zakat institutions.

\section{Analytical Framework}

\subsection{Zakat, Infaq, Shadaqah/Alms (ZIS)}

Zakat in a word means purifying, growing or developing. Whereas in terms of zakat means issuing a number of assets to people who have the right to receive (mustahik) in accordance with Islamic law (Wibisono, 2015). Zakat is a maaliyyah ijtima'iyyah worship which has a very important position, is strategic and determines both in terms of Islamic teachings and in terms of developing the welfare of the society (Hafidhuddin, 2002). The existence of zakat is considered as ma'luum minad-in bidh-dharuurah which is automatically known and becomes an absolute part of one's Islam (Yafie, 1994).

In the Al-Quran, there are about 35 verses which discuss zakat, 27 of which the word "zakat" is always juxtaposed with the word "prayer". This shows that zakat and prayer have equal positions (IZDR 2009). Some scholars believe that whoever leaves zakat then he has left the prayer, and vice versa. Allah SWT said:

"And establish prayer and give zakah and bow with those who bow [in worship and obedience].” (Al-Baqarah, 2:43)

"...........But if they should repent, establish prayer, and give zakah, let them [go] on their way. Indeed, Allah is Forgiving and Merciful." (At-Tawbah, 9:5)

Infaq comes from the word nafaqa which means to leave. Whereas according to the term infaq is to issue something (property) for the benefit of being ordered by Allah SWT. Infaq has 2 characteristics, namely compulsory and sunnah. Forms of compulsory infaq are expiation, nadzar, livelihood, etc. While the form of sunnah infaq is infaq to the poor, assistance from natural disasters, etc. Sunnah or voluntary information is an addition to zakat.

"The example of those who spend their wealth in the way of Allah is like a seed [of grain] which grows seven spikes; in each spike is a hundred grains. And Allah multiplies [His reward] for whom He wills. And Allah is all-Encompassing and Knowing." (Al-Baqarah, 2:261)

Alms or Sadaqah come from Arabic which means honest or true. Alms can be interpreted as evidence of honesty or the truth of one's faith. Alms is voluntary without the provisions of nishab, haul, and asnaf. The scope of Alms is wider than zakat and infaq. Alms is not only in the form of property or material, but can be in the form of actions such as helping others, keeping words, smiles, etc. An alms is also a form of jariyah charity. Allah SWT gives many rewards for the Muslims who give charity, such as eradicating sins, multiplying merit, extinguishing the tormenting fire, extending the chest, extending the age, etc. The messenger of Allah -peace and prayer of Allah be upon him- said:

"Giving alms can erase sins just like water ceases fire." (Narrated by Tirmidhi, classed sahih by Al Albani in Shahih At Tirmidzi, in hadith no. 614)

"Wealth will not be decreased by giving by giving charity. And a forgiving slave must be rewarded by Allah with authority." (Narrated by Muslim, no. 2588) 


\subsection{Performace of Zakat Institutions}

Performance is the result of an activity (Robbins \& Coultr, 2009). The performance also refers to the level of success and the ability to carry out tasks and achieve predetermined goals (Gibson, Ivancevich, \& Donnely, 1994). From this definition, it can be concluded that performance is an achievement of the results of an activity that refers to the ability to carry out tasks in accordance with the stated goals.

The United Nations Development Program (UNDP "Governance and Sustainable Human Development, 1997") states that performance is part of good governance. Related performance by fulfilling the interests of stakeholders by utilizing resources as well as possible. Performance can include cost-effectiveness, capacity, responsiveness, dissemination of information to the public, monitoring and management evaluation (Graham, Amos, \& Plumptre, 2003).

Zakat institutions is an Islamic institution that aims to reduce poverty and ensure social justice (Kasri \& Putri, 2018). The core activity of zakat institutions is to collect ZIS funds from Muslims who have fulfilled the requirements and distribute the funds to those who are entitled to (mustahik). In addition to managing funds in accordance with Islamic law, zakat institutions must also be managed efficiently and professionally. Zakat institutions must also implement good governance because it contributes to the efficiency and effectiveness of managing ZIS funds(Wahab and Rahim Abdul Rahman, 2011). Zakat institutions which implements good governance is a responsible, transparent and fair organization. Zakat institutions who do not implement good governance can reduce public trust. Negative perceptions of the zakat management if unhandled can have a negative impact on the development of the zakat institutions. Therefore, the measurement of zakat institutions performance is very important in maintaining public trust (Noor et al., 2015).

\section{Method}

This research is a quantitative research using Data Envelopment Analysis (DEA) to measure zakat institutions performance in 2017. As for measuring performance in terms of zakat institutions efficiency, the author uses the DEA method with DEAP version 2.1 application.

The data used in this study are primary and secondary data. Primary data is obtained directly from respondents through interviews with informants determined by BAZNAS and BAZIS. Meanwhile, secondary data is obtained from financial reports and literature studies.

Data Envelopment Analysis (DEA) is a non-parametric method to measure the relative efficiency and managerial performance of a Decision Making Unit (DMU). Based on Charnes et al (1978), DEA was initially widely used in the banking industry, but DEA can also be applied to several industries, one of which is the zakat institution. Measurement of efficiency is measured by how far the production point of a particular DMU is to the efficient frontier point. An efficient DMU will get a value of 1 , the closer to 0 the DMU is declared inefficient. This method also makes it possible to know the source of inefficiencies from each input or output and see how efficient the input and output inefficiencies can be.

DEA was first introduced by Charnes, Cooper, and Rhodes in 1978. This method has a relative calculation result. The efficiency value can be measured by calculating the ratio between the weighted amount of output and the number of weighted inputs. The efficiency of DMU calculation formulation can be formulated as follows: 


$$
\text { Efistensi unit } j=\frac{u 1 y 1 j+u 2 y 2 j+\cdots}{v 1 x 1 j+v 2 x 2 j+\cdots}
$$

Where,

$$
\begin{array}{ll}
\mathrm{u}_{1} & =\text { weights for output } \mathrm{i} \\
\mathrm{y}_{1 \mathrm{j}} & =\text { output } 1 \text { from unit } \mathrm{j} \\
\mathrm{v}_{1} & =\text { weights for input } 1 \\
\mathrm{x}_{1 \mathrm{j}} & \quad=\text { input } 1 \text { for unit } \mathrm{j}
\end{array}
$$

DEA has several approaches to see the relationship between input and output. In Hadad et. al (2003) there are three approaches to see the relationship of input and input for financial institution using both parametric and non-parametric methods, namely the production approach, the intermediation approach and the asset value approach. The production approach sees financial institutions as producers from deposit accounts and loan loans. The intermediation approach sees financial institutions as intermediaries who transfer and convert financial assets from surplus units to deficit units. Finally, the asset value approach is almost similar to intermediation, which sees financial institutions as producers of loan loans in the form of assets.

DEA has two models, namely the BCC and CCR models. The BCC model was developed by Banker, Charner, and Cooper (1984). The BCC model states that competition and financial constraints can cause companies not to operate on an optimal scale. This problem is overcome by assuming the Return to Scale Variable (VRS), meaning that the addition of input of $\mathrm{n}$ times will not result in an increase in output $\mathrm{n}$ times (can be smaller or larger). This condition will lead to Increasing Return to Scale (IRS) and Decreasing Return to Scale (DRS). An efficient DMU on this model is called technically efficient. While the CCR model was developed by Charnes, Cooper, and Rhodes (1978). This model assumes that the addition of input of $\mathrm{n}$ times will increase the output of $\mathrm{n}$ times or also called Constant Return to Scale (CRS). An efficient DMU in this model is called overall efficiency, which is technically efficient and scale.

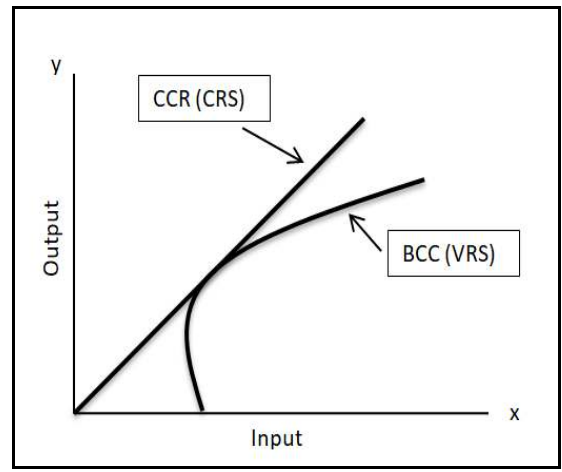

Fig.1. Efficiency CRS and VRS

Source : (Coelli, Rao, O'Donner, \& Battese, 2005)

The picture above shows the difference in efficiency based on CRS and VRS. The line with upward sloping shows the frontier line with the CRS model that describes the DMU's performance on an optimal scale. While the curved line shows the frontier line with the VRS model which describes the DMU's performance on technical efficiency. 
This study uses a production approach that sees zakat institutions as a producer that generates collected funds, channeled funds and the number of muzakki and munfiq. The author chooses an output orientation because Indonesia has a large potential for ZIS but the realization of ZIS collection is still low. This study also uses the CCR model which has CRS assumptions. There are 2 inputs and 3 outputs, the input is operating expenses (which are all expenses that include all expenses except salary and benefits expense) and the number of amil. While the output is ZIS collection, ZIS distribution and the number of muzakki and munfiq.

\section{Result And Discussion}

The table below is the results of the performance of BAZNAS and BAZIS in Jabodetabek as measured by DEA. The table below explains the results of the efficiency of BAZNAS and BAZIS in Jabodetabek. There were 7 DMUs in 2016 and 9 DMUs in 2017 which were BAZNAS and BAZIS in Jabodetabek. The difference in the amount of DMUs in that years was due to the limited data obtained by the author.

Table 2. DEAP's Calculation Results *in Million Rupiahs

\begin{tabular}{lcc}
\hline & 2016 & 2017 \\
\hline Number of DMU & 7 & 9 \\
\hline DMU's efficient & 2 & 4 \\
\hline Mean & 0.642 & 0.752 \\
\hline Min & 0.079 & 0.125 \\
\hline Max & 1.000 & 1.000 \\
\hline St. Dev & 0.316 & 0.355 \\
\hline Input Slacks & \\
\hline Number of Amil & 1.320 & 0.000 \\
\hline Operating Expense* & 3.830 & 0.000 \\
\hline Output Slacks & \\
\hline ZIS Collection* & 1043.981 & 1039.353 \\
\hline ZIS Distribution* & 1026.811 & 468.986 \\
\hline Number of muzakki and munfiq & 0.00 & 473.276 \\
& 0 & \\
\hline
\end{tabular}

Source: Processed by Author

Based on the table above, the average efficiency of BAZNAS and BAZIS in Jabodetabek is 0.642 and 0.752 in 2016 and 2017. The maximum value of efficiency is 1 . In 2016 there were 2 DMUs that were already efficient, namely BAZIS Administration of South and East Jakarta. While in 2017 there were 4 DMUs that were already efficient, namely BAZIS Administration of South and East Jakarta and BAZNAS Bekasi and Tangerang. Input slacks show that the average input value can be reduced so that the DMU can reach the frontier efficiency point. From the input side there are no inefficiencies in 2017 but in 2016 there are inefficiency on the variable number of Amil and operating expense. On the other hand, Output slacks show an average output value that can be increased so that the DMU can reach the frontier efficiency point. ZIS collection and distribution have inefficiencies in both years but number of muzakki and munfiq only have efficiencies in 2017. The output slacks on ZIS collection and distribution variable decreased, so it can be said that BAZNAS and BAZIS in Jabodetabek improve the efficiencies in both variables. 
Table 3. Rank of Efficiency Performance of Zakat Institutions

\begin{tabular}{clcccc}
\hline \multirow{2}{*}{ No } & \multirow{2}{*}{ DMUs } & \multicolumn{2}{c}{2016} & \multicolumn{2}{c}{2017} \\
\cline { 3 - 6 } & & Efficiency & Rank & Efficiency & Rank \\
\hline 1 & $\begin{array}{l}\text { South } \\
\text { Jakarta }\end{array}$ & 1.000 & 1 & 1.000 & 1 \\
\hline 2 & East Jakarta & 1.000 & 1 & 1.000 & 1 \\
\hline 3 & Tangerang & - & - & 1.000 & 1 \\
\hline 4 & Bekasi & 0.518 & 5 & 1.000 & 1 \\
\hline 5 & West Jakarta & 0.704 & 2 & 0.877 & 2 \\
\hline 6 & $\begin{array}{l}\text { Central } \\
\text { Jakarta }\end{array}$ & 0.610 & 3 & 0.832 & 3 \\
\hline 7 & North & 0.581 & 4 & 0.767 & 4 \\
& Jakarta & & & & \\
\hline 8 & Bogor & 0.079 & 6 & 0.163 & 5 \\
\hline 9 & Depok & - & - & 0.125 & 6 \\
\hline
\end{tabular}

Source: Processed by Author

Table 3 shows the results of the efficiency of BAZNAS and BAZIS in Jabodetabek in 2016 and 2017. It can be seen that in 2016 there were 2 DMUs that were efficient, namely BAZIS Administration of South and East Jakarta. That zakat institutions get the highest ranking. While, 5 DMUs are not efficient yet. BAZNAS Bogor has the lowest efficiency value in 2016 which BAZNAS Bogor placed in the last rank among other DMUs.

On the other hand, in 2017 there were 4 DMUs that were efficient, namely BAZIS Administration of South and East Jakarta, BAZNAS Tangerang, and Bekasi. The four zakat institutions get the highest ranking. While, 5 DMUs are not efficient yet. BAZNAS Depok has the lowest efficiency value in 2017 which BAZNAS Depok occupy the last rank among other DMUs.

\section{Conclusion}

There is conclusion from result of this research. Efficiency measurement based on data envelopment analysis with output orientation CCR model shows the average performance of BAZNAS and BAZIS in Jabodetabek is 0.642 and 0.752 in 2016 and 2017. The value of efficiency increased so it can be said that BAZNAS and BAZIS in Jabodetabek improve the efficiencies. There were 2 and 4 DMUs that were efficient in 2016 and 2017. There were 2 DMUs that were efficient in both years namely BAZIS Administration of South and East Jakarta.

\section{Recommendation}

BAZNAS and BAZIS in Jabodetabek can make zakat maps in their respective regions both in terms of muzakki and mustahik so as to provide an overview of the potential and distribution of zakat in the region.

BAZNAS and BAZIS in Jabodetabek can increase the socialization of ZIS both direct socialization and social media as well as transparency in the collection and distribution of ZIS funds in both media so as to increase public awareness and trust in the importance of paying zakat to institutions formal. 
The Central of BAZNAS can provide information related to zakat institutions financial statements throughout Indonesia as is done by Bank of Indonesia in relation to the publication of bank financial reports throughout Indonesia so that the zakat institutions financial statements can be accessed easily by the wider community and subsequent researchers and data can be obtained easily.

In addition, Central of BAZNAS can also make performance ratings from zakat institutions throughout Indonesia. Rating can be done once a year. With the measurement of zakat institutions ratings throughout Indonesia, it is expected to be an evaluation material and motivation for the Amil of zakat institutions so that performance is increasing every year.

The researcher can further increase the number of zakat institutions studied, compare government and community zakat institutions on the same scale, using different input-output variables so as to provide a broader picture. In addition, it can measure the efficiency with other methods such as the parametric method, namely SFA (Stochastic Frontier Analysis).

\section{References}

[1] Al-Qur'an Al-Karim

[2] Abdullah, M. and Sapiei, N. S. (2018) 'Do religiosity, gender and educational background influence zakat compliance? The case of Malaysia'. doi: 10.1108/IJSE-032017-0091.

[3] Ahmed, H. and Md Salleh, A. M. H. A. P. (2016) 'International Journal of Islamic and Middle Eastern Finance and Management Article information ':

[4] Abu Bakar, M. H., \& Abd. Ghani, A. H. (2011). Towards Achieving the Quality of Life in the Management of Zakat Distribution to the Rightful Recipients (The Poor and Needy). International Journal of Business and Social Science Vol. 2, 237-245.

[5] Ahmed, H. (2004). The Role of Zakah and Awqaf in Poverty Alleviation. Jeddah: Islamic Research and Training Institute, Islamic Development Bank.

[6] Akbar, N. (2009). Analisis Efisiensi Organisasi Pengelola Zakat Nasional dengan Pendekatan Data Envelopment Analysis. Islamic Finance \& Business Review Vol. 4, 760-784.

[7] al-Qaradhawi, Y. (1973). Fiqh az-Zakat. Beirut: Muassasat ar-Risalah

[8] al-Qaradhawi, Y. (1999). Hukum Zakat. Bogor: Litera Antara Nusa.

[9] Ardianto, W. (2018, Januari 18). Liputan 6. Retrieved Juni 10, 2018, from https://www.liputan6.com/read/3230831/perkembangan-depok-kian-mencolok

[10] Boyne, G., \& Williams, J. G. (2003). Public Management Review. London: Routledge.

[11] Coelli, T. J., Rao, D. P., O'Donner, C. J., \& Battese, G. E. (2005). An Introduction to Efficiency and Productivity Analysis. New York: Springer Science+Business Media, Inc.

[12] Dardak, H. (2014, 02 19). Jabodetabek Calon Megapolitan Terbesar ke-2 di Dunia. (D. Finance, Interviewer)

[13] Djaghballou, C. E., Djaghballou, M., Larbani, M., \& Mohamad, A. (2017). Efficiency and productivity performance of zakat funds in Algeria. International Journal of Islamic and Middle Eastern Finance and Management..

[14] Farrel, M. J. (1957). The measurement of productive efficiency. Journal of the Royal Statistical Society, 253-290.

[15] Gibson, J. L., Ivancevich, J. M., \& Donnely, J. H. (1994). Organizations: Behavior, Structure, Processes. New York: McGraw-Hill. 
[16] Graham, J., Amos, B., \& Plumptre, T. (2003). Principles for good governance in the 21st century. Ottawa: Institute On Governance.

[17] Hadad, M. D., Santoso, W., Ilyas, D., \& Mardanugraha, E. (2003). Analisis Efisiensi Industri Perbankan Indonesia: Penggunaan Metode Nonparametrik Data Envelopment Analysis. Jakarta: Bank Indonesia.

[18] Hamzah, A. A., \& Krishnan, A. R. (2016). Measuring the efficiency of zakat collection process using data envelopment analysis. AIP Conference Proceedings. American Institute of Physics.

[19] Kasri, R. A., \& Putri, N. I. (2018). Does Strategic Planning Matter in Enhancing Performance of Zakah Organization? Some Insights from Zakah Management in Indonesia. International Journal of Zakat Vol.3, 1-21.

[20] Khurshid, M. A. et al. (2014) 'Competitiveness Review'.

[21] M., H. Z. (1991). Economic Functions of an Islamic State (The Early Experience). Leicester: The Islamic Foundation.

[22] Noor, A. H. M. et al. (2015) 'Efficiency of Islamic Institutions: Empirical Evidence of Zakat Organizations' Performance in Malaysia', Journal of Economics, Business and Management, 3(2), pp. 282-286. doi: 10.7763/JOEBM.2015.V3.195.

[23] Robbins, S. P., \& Coultr, M. (2009). Management. New York: Pearson Education, Inc.

[24] Wahab, N. A. and Rahim Abdul Rahman, A. (2011) 'A framework to analyse the efficiency and governance of zakat institutions', Journal of Islamic Accounting and Business Research, 2(1), pp. 43-62. doi: 10.1108/17590811111129508.

[25] Wibisono, Y. (2015). Mengelola Zakat Indonesia. Jakarta: Prenadamedia Group.

[26] Yafie, A. (1994). Menggagas Fiqih Sosial. Bandung 